\title{
Tackling with Refugee Children's Problems in Turkish Schools
}

\author{
Aysun Dogutas \\ Correspondence: Aysun Dogutas, Ph.D., Education Faculty, Pamukkale University, Denizli, Turkey.
}

Received: April 6, 2016 Accepted: April 19, $2016 \quad$ Online Published: April 21, 2016

doi:10.11114/jets.v4i8.1524

URL: http://dx.doi.org/10.11114/jets.v4i8.1524

\begin{abstract}
The main aim of this study is to produce a solution to improve the refugee and asylum seeker students' adaptation to the Turkish schools and classrooms by using action research approach which is often preferred for solving the problems encountered by the educators. The sample of the study consists of selected students at a primary school in Denizli province in 2014-2015 academic years. This sample consists of one school and 14 students. It uses qualitative data collection tools including teacher and principal interviews, student interviews, and observation of the researcher and implementers. Results showed that the action research is useful. Having special education helped refugee and asylum seeker students to read, write and speak the Turkish language quicker and have communication and adaptation to their classmates and teachers easier.
\end{abstract}

Keywords: refugee children, students, education, action research

\section{Introduction}

After World War II, most of the people around the world had to migrate from the places they were born toward other locations due to changing dynamics such as nations' trying to gather homogeneous populations. Millions of people have been affected during this period. Starting from World War II, reasons of migration from less developed or developing countries toward developed countries differs as economic, politic, social, cultural, etc. In this context, economic trouble, war, terror, political disorganization and segregation depended on ethnicity; religion and gender take part at the forefront (Icduygu \& Toktas, 2002, p. 27). In 2008, there were about 12 million refugees or asylum seekers worldwide (U.S. Committee for Refugees and Immigrants, 2006).

The first ten countries, that people who make the application for asylum prefers are United States, France, Germany, Sweden, England, Canada, Belgium, Dutch, Australia and Switzerland. Statistics shows that illegal refugees mostly come from Iraq, Pakistan, Afghanistan, Moldova, Palestine, Georgia and Somali (Atasu Topcuoglu, 2012). Eventually, Turkey became one of the countries that thousands of people prefer to migrate illegally and disorganized. According to this perspective, Turkey is not only a transit country for refugees but also a target one. Turkey became a place for refugees from many countries such as Syria, Iraq, Iran and Afghanistan. The rates of refugees and asylums are increasing day by day in Turkey. In this flow of migration, of course, there are many cases which haven't been in statistics.

Parallel to global dynamics, the number of irregular refugees increasing in Turkey. As the date of 31 January 2013, the total number of refugees is 19,203 and asylum seekers are 13,703 except Syrians. Then it reached 21,956 of refugees and 14,758 of asylum seekers in June of the same year (Kartal \& Basci, 2014).

Just to go another country, many of these refugees come to Turkey and stay between six months to two years. In this flow of migration, of course, many innocent children had to leave their homes, toys, schools and friends. While their parents try to get a visa for a European country or America, these kids continue classes in Turkish schools in Turkey. Within determined illegal migration, children's rate is $17 \%$ of adults. This number shows that children are an importantly large group in irregular migration (Atasu Topcuoglu, 2012). Even though the number of refugee and asylum seeker children is a considerable amount, there are many difficulties refugee and asylum seeker children faced with at host countries' schools.

There have been many negotiations among countries about refugees and asylum seekers, especially in education. "The 1989 Convention on the Rights of the Child meant that governments and agencies could not argue that education of refugees or internally displaced children should wait until they returned home since there is no way to be sure whether the wait will be for weeks, months, years or decades. The Convention obliges governments to promote or facilitate 
access to education for children within their territory, regardless of their status. Even children who are asylum-seekers must have access to education. The Convention on the Rights of the Child requires governments to promote free and compulsory schooling at primary level, access to secondary schools, and access to tertiary education on the basis of capacity by every appropriate mean" (Sinclair, 2007, p. 52).

Education is crucial particularly for people who left their homes, countries, and relatives regarding the future of their children and society. According to Sinclair (2007), "Education in emergencies can help to provide a sense of normality, restore hope through access to the 'ladder' of education and support psychological healing from traumatic experiences through structured social activities in a 'safe space'... (p. 52)".

Responsibility for promoting children's access to quality education rests primarily with national governments (Sinclair, 2007). Thus, Turkey should support quality education for refugee and asylum seeker children.

According to the Ministry of National Education (MEB) statistics, foreign national students at the primary and secondary school are mostly from Afghanistan, Iraq, Azerbaijan, Iran and Bulgaria. However, since missing out on statistics for the number of refugee children at the school age in Turkey, there aren't legal numbers of active participation to education (Atasu Topcuoglu, 2012). However, 90\% of refugee and asylum seekers' children don't take place at the primary school process (Kartal \& Basci, 2014). Since awaiting the process of refugee and asylum seekers' to get the residence permit from another country may take years, it is important for these children's being in the core education system in Turkey. Not being in the primary school system of refugee and asylum seekers' children at substantial proportion, Turkey should make the refugee legislation and application process better. Since only $64 \%$ of refugee and asylum seeker children can go to school (Kartal \& Basci, 2014).

When we look at the organization of rights of refugee law, it seems that for a long time, there hasn't been a holistic legislation. 1994 regulation didn't provide a particular procedure for children; however, the statute provides asylum applicants and refugees' children to participate in training (Atasu Topcuoglu, 2012). Besides, Ministry of National Education had issued a circular in 2010 about foreign national children's utilization of education and training opportunities. Also, foreigners' law effectuated in 2014 was one of the legal steps (Recber, 2014). In the following part, some articles determined in 2010 circular and issued by the Ministry of National Education will be presented.

In 2010 circular, MEB accepted that there are some troubles with the education of refugee and asylum seeker children. They stated that "according to the sensations and requests reverted to the Ministry, it can be understood that some troubles and hesitations on foreign nationals' utilization of education and training are being lived" (MEB Genelge, 2010). Since MEB has realized the problem, it issued a circular to make better foreign nationals' children's attending primary education in Turkey. Here are some articles from that circular;

- School/Institutions and public education centers will teach Turkish and help them to gain professional skills. Also, MEB will provide all kinds of supportive teaching and training studies' planning and applications in case of desirability and of appropriateness of the place (MEB Genelge, 2010).

- Necessary precautions will be taken by school administrations, counseling services, counseling and research centers and commission to improve refugee or asylum seeker students' retention of their training compatible with school, environment, and other studentsand. Also necessary support and help for students who are having trouble to get adaptedprecautions will be madeschool available for them by those institutions (MEB Genelge, 2010).

Even though MEB issued a circular in 2010, Recber (2014) stated that "refugee and asylum seeker children, continuing education at the country they had migrated, face with challenges such as segregation, not having friends, language problems and these are social adaptation obstacles they face and live." Many studies also argued that even though Turkey is trying to solve the problems refugee and asylum seeker children confront with education, there are still many challenges that refugee and asylum seeker students face at schools and their parents face in the society (Kartal \& Basci, 2014; Atasu Topcuoglu, 2012; Seydi, 2014, Yildiz, 2013).

How can national governments promote quality education for refugee and asylum seeker children? Teachers are the key to quality, but many are new to the profession, untrained and lacking in confidence (Winthrop \& Kirk, 2005). Or even experienced teachers have not been trained. Additionally, individual programs may be needed to help children and adolescents. Youth can play a significant role in prioritizing education and training needs of young people (WCRWC, 2001, 2002, 2005). Also, class size should be monitored closely crowded ones should be avoided since children affected by crisis may have difficulties in concentrating or may suffer from lack of support at home, and so need the maximum attention from the teachers (Sinclair, 2007). Lastly, the curriculum should initially reconsider where refugee and asylum seeker children exist. It is the goal of this study to apply a unique program for refugee and asylum seeker children to promote quality of these kids' education in Turkish schools. 


\subsection{Problem Status}

Why refugee and asylum seeker children's education is important? According to the Gardiner and Gander, 6-10 years is a period of attending teaching and developing role model for children; and for children's development teachers' existence and relations in school are important (2001). However, the International Organization of Migration (IOM) Report determined that in all interviews with refugee and asylum seeker children and parents, all groups except Bulgarian refugees having problems in accessing education. For the lives of children of these ages, friends are important.

However, a group of friends of these kids is limited and even if they have some friends these are from their community (Atasu Topcuoglu, 2012). These show that refugee and asylum seeker children are having trouble in accessing education in Turkey. Even though Turkish government tries to provide education to these children, there are many lacks in education refugee and asylum seeker children. Of course, they can go to school as registered or a guest student. However, they cannot read, write or understand Turkish. Teachers don't have time to interest in them individually. Thus, most of them don't know what their educators and friends are talking about. Also, these children don't have Turkish friends; their friends are also foreign national children. There should be an extra program for these kids to teach Turkish and have adaptation period to Turkey.

\subsection{Problem Statement}

Even though Turkey is trying to make the asylum policy better for foreign national children, there are many obstacles that these children are facing in schools. This is due to lack of individualized special education. These kids need an extra or additional program to be able to get adapted to the rest of the class and school they attended. What can be done to be able to get these children adapted to their classes, friends, teachers, schools, and Turkey?

\subsection{Research Objective}

The aim of this study is to produce solutions to improve the refugee and asylum seeker students' adaptation to the Turkish schools and classrooms by using action research approach preferred for solving the problems encountered by the educators.

\section{Method}

With the aim of producing solutions to improve the refugee and asylum seeker students' adaptation to the Turkish schools and classrooms "action research" was used (Westhues \& others, 2008; Andrew \& Halcomb, 2009; Cooper-Twamley, 2009, Yuladir \& Dogan, 2009). Action research is defined by Schmuck (1997) as an attempt to "study a real school situation with a view to improve the quality of actions and results within it" (p. 28). McMillan (2004) describes action research as being focused on solving a particular classroom or school problem, improving practice, or helping make a single decision at a local site. The overarching goal of action research is to improve practice immediately within one or a few classrooms or schools (McMillan, 2004).

\subsection{Participant (Subject) Characteristics}

The participants of this study were the refugee and asylum seeker students attending at a primary school in the center of Denizli during the spring semester of 2014-2015 academic years. This study used the purposive sampling by selecting participants since there has been a problem with the adaptation of refugee and asylum seeker students with Turkish children and teachers. All of the refugee and asylum seeker students in that school $(n=14)$ attended to the study.

\subsection{The Place of the Study}

The researcher selected the most appropriate place to be able to work with the refugee and asylum seeker students. Since all of the classrooms were full and there was someone in the teachers' room all the time, meeting room of the school was chosen as the workplace. Also, in the meeting room, there was a computer that students would work on letters and words by listening and seeing.

\subsection{The Process of the Study}

Mertler introduced the general process of conducting an action research as follows;

1- Planning stage
a. Identifying and limiting the topic
b. Gathering information
c. Reviewing related literature
d. Developing a research plan

2- Acting stage 
a. Collecting data

b. Analyzing data

3- Developing stage

a. Developing an action plan

4- Reflecting stage

a. Sharing and communicating results

b. Reflecting on the process (2014, p. 37)

The process of this study was designed as planning stage, acting stage, developing, stage and reflecting stage as suggested by Mertler (2014). The researcher followed the nine steps of Mertler to be able more organized.

\subsubsection{Planning Stage}

The researcher started with the planning stage. The first step in any research study is deciding what exactly to study (Mertler, 2014, p. 39). Thus, the researcher identified the topic of the study as "problems of asylum seeker or refugee children facing at schools in Turkey." The researcher had witnessed many asylum seekers, or refugee children are sitting down alone during the break time or having been pushed by Turkish students at the school garden. Since the goal of any action research study is a desire to make things better, improve some specific practice, or correct something that is not working as well as it should (Fraenkel \& Wallen, 2003), the researcher identified the problem and aimed to solve this issue. Identified topic must be manageable to investigate a topic for action research (Fraenkel \& Wallen, 2003) to study. Thus, the researcher limited to the subject as an adaptation of asylum seeker or refugee students' to the Turkish schools.

The second step of action research is to gather information. Information gathering can be as simple as talking with teachers, counsellors, or administrators in school to evaluate their perceptions of researchers' proposed research problem and perhaps query them for ideas (Mertler, 2014). To gather broad information the researcher visited the administrators of two primary schools in the city center of Denizli in which the researcher knew that there were refugee and asylum seeker students. Officials defined asylum seeker or refugee students' adaptation to Turkish schools as a problem since most of these children don't know Turkish, and teachers don't have time to interest in these students. Additionally, provincial directorate of national education doesn't provide any additional teacher for these children.

After identifying and limiting the topic, the researcher reviewed the related literature as the third step. At this stage, the researcher reviewed the reports done with refugee and asylum seeker people. This related literature can guide defining or limiting the problem, for developing the appropriate research design, or for selecting legitimate instruments or techniques for collecting the data (Parsons \& Brown, 2002). There had been a limited study done with refugee and asylum seeker children in Turkey. Most of the studies done with refugee and asylum seekers are conducted at camps that they are living right now. However, there aren't many pieces of research for the people living outside the camps and for their problems. Also, most of the studies only showed the problems of refugee and asylum seekers as education, housing, job, etc. without providing any solution. Again, this study will provide "an opportunity to connect existing theory and research to actual classroom practice" (Johnson, 2008).

As the last step of the planning stage, the researcher developed a research plan. The development of a study plan consists of identifying the research problem and variables which will lead to collect data. At this stage, the researcher identified the research question as "What can be done to be able to get these children adapted to their classes, friends, teachers, schools, and Turkey?" Mertler (2014) stated that "integrated into the specification of research questions and hypotheses is the identification of the variables that are central to the action research investigation" (p. 40). Thus, the researcher defined the variables as "answering Turkish questions, speaking Turkish, talking to Turkish people". As Mertler (2014) stated it is critical that variables be observable and measurable. Decisions on the research question and variables are the procedures to be used to collect data mainly design of the research study. With these variables the researcher decided the procedures of data collection. The action researcher needs to determine who can provide the data that are needed, how many participants are needed for the study, and how to gain access to those individuals (Creswell, 2005). Thus, the researcher decided to do the study in a school which has 14 refugee and asylum seeker students. As stated above, the researcher interviewed with two school administrators. However, in one of these schools, there had been 60 refugee and asylum seeker students. The researcher decided to study with the school which has 14 refugee and asylum seeker students. Teacher and students interviews will be used to collect data. Since teachers are the ones who work with refugee and asylum seeker students and know their situations better and as stated above they are the key to quality education their opinions are important. To be able to observe the level of students' Turkish and adaptation to Turkey, interview with these children will be useful. Thus, interviewing with the teachers and refugee and asylum seeker students will be the way of data collection. 


\subsubsection{Acting Stage}

The acting stage includes two steps. One is implementing the plan and collecting data and the second step is analyzing the data. At the implementing the plan and gathering data step decisions must be made about the instruments or other data collection techniques that will be used in the study (Mertler, 2014, p. 41). Fraenkel and Wallen (2003) suggested three data collection methods in action research. These are observations, interviews and examination and analysis of existing documents or records. Mertler (2014) added the fourth technique to Fraenkel and Wallen (2003) as quantitative measures. Since action research allows researchers to use many kinds of data collection techniques, it is possible to use both qualitative and quantitative methods. In this study, the researcher decided to use qualitative methods since most of the asylum seeker and refugee students don't know Turkish; thus, they cannot answer questionnaires.

At this stage, the researcher made the last decisions and data collection methods. Data collected by interviews with both teachers and students. In teacher interviews the researcher invited all teachers in whose classroom there is an asylum seeker or refugee student to the meeting room and interviewed with them one by one. After interviewing with teachers, the researcher invited 14 students to the conference room and interviewed one by one. During the interviews, the researcher asked teachers about their students' Turkish language level, adaptation to them and classroom, the level of students according to the stage standard, students' parents and socio-economic situation. The researcher noted all the interviews since teachers didn't allow to be recorded. To check what the teachers told, the researcher also interviewed with the students. The researcher prepared interview questions which consist of ten questions. These issues are about their families, lives, countries, and classrooms they are attending now. However, since some of these children don't know Turkish, they couldn't answer the researcher's questions. Some gave wrong answers to the questions. The researcher only communicated with two of them.

The following step is analyzing the collected data. In action research, "as you collect data, analyze them by looking for themes, categories, or patterns that emerge. This analysis will influence further data collection by helping you to know what to look for" (Johnson, 2008, p. 63). Thus, the researcher started to analyze the data after the interviews with teachers. According to the themes or patterns emerging from teacher interviews, the researcher planned the student interviews. During the interviews, the researcher also observed the students and their communication with Turkish children. Thus, the observation was another data collection method used in this study. The analysis of action research data is usually less complex and detailed than others (Fraenkel \& Wallen, 2003). Additionally, as Creswell (2005) stated, it is not a requirement for the researcher to analyze the data; the researcher is certainly free to enlist the help of teachers, administrators, or data analysts. Even though it is not a requirement to analyze the data, the researcher analyzed the interviews and listed the emerging categories and themes both from teacher and student interviews. According to the teacher interviews; emerging issues were; asylum seeker or refugee students don't know Turkish well. Thus, they cannot communicate with the teacher or other students and cannot adapt to the school. According to the student interviews, students who know Turkish a little are good at lessons and get in contact with others; on the other hand, students who don't know Turkish cannot talk with the teacher, other students or strangers. They only speak with students like themselves (asylum seeker or refugee). Of course, students who know Turkish and can adapt easily are fewer (only three of them) while students having communication and adaptation problem are more.

As a result of teacher interviews, it has been observed that teachers don't have time to get interested in these children. Most of the teachers even don't know the nationality and parents of the students. Teachers don't work away with these kids. These kids only come to school and sit down during the classes. First-grade students can write and read the books. However, it was observed during the students' interviews that although students read the books, they don't know the meaning of the text they were reading.

\subsubsection{Developing Stage}

In developing stage, the researcher should draw up an action plan. After analyzing the data and the results of the analysis interpreted, the following step in action research is the development of an action plan (Mertler, 2014). Thus, the researcher developed an action plan to solve the problem of refugee or asylum seeker students as Creswell (2005) stated that the important outcome from the development of an action plan is the existence of a concrete and tangible approach to trying out some new ideas as a means to solve the original problem.

The action plan for this study is seeking to teach Turkish language and some basic communication phrases to the refugee and asylum seeker students. Even though teachers try to help these children in the classroom, they cannot assist them since there are other students in the class. Thus, the researcher and the administrator of the school decided to pay particular education to these children one by one. This solution was one of the solutions suggested by Winthrop and Kirk (2005). This training will be given by some instructors outside the school. To be able to help all the students individually, 15 University students have been chosen for the education. These instructors were from counselling department of the university since they would know how to reach these children since they had taken educational 
psychology and counselling methods classes. These college students will be called as "instructor" for the rest of this study. Instructors were chosen voluntarily. Each refugee or asylum seeker student was assigned to an instructor. Since each refugee or asylum seeker students' needs are different, each instructor would teach whatever these students need. At the first meeting, instructors introduced themselves and decided what they should do with their child after talking to students and their teachers. After the first session of students and instructors, the researcher gathered all instructors and guided them how they should behave and what they should be careful about. Also, instructors told us what they need for the training. The researcher and administrator supplied computer, CDs, notebooks, books and some gifts for the students. Each instructor determined days and hours they can meet with students by consulting students' teachers. According to the action plan, instructors' continued to the special education almost three months. Approximately every two weeks the researcher and instructors gathered and talked about the issues or situations of the students and training. Additionally, instructors always have a connection with students' teachers and the researcher. The aim of the action research was to teach Turkish, and some basic communication phrases to these children since the main problem of these kids are language. They cannot understand Turkish speaking and cannot express themselves in Turkish. The action plan was developed and implemented stage by stage as the researcher's formal document as Mertler stated: "in some situations, it may be necessary to prepare a formal report outlining action plan" (2014, p. 43).

\subsubsection{Reflecting Stage}

After developing and implementing an action plan, the eight step is sharing and communicating the results. Mertler (2014) stated that "an important part of any research study is the reporting or sharing of results with others in the educational community at large" (p. 43). These communities can be teachers, principals, other school teachers, school boards or parents. Additionally, at a more professional level, results can be shared at academic or vocational journals as Johnson (2008) stated. Or the results can be presented at academic conferences. The results of this study are aimed to share in an academic journal. What are the results of this action research? The following section will provide the results of the study.

At the end of the semester the researcher gathered the instructors and discussed what happened during the action research. Some of the instructors stated that "some refugee or asylum seeker students didn't come to school regularly that they couldn't have had regular lessons". Some of the instructors said that "they had very real time with students, and the students are better than they first started to lessons." After having a conversation with instructors, the researcher had interviews with teachers of these students and with refugee and asylum seeker children. According to the interviews, results as follows;

\section{This particular education is helpful for asylum seeker or refugee children.}

Teachers stated that "having face to face lessons are very useful for these children". Since they cannot help these kids during the classes, this particular education is very helpful for them. Some of the teachers stated that "now these children can read and write; also they communicate with us". At the end of the action research, some of these refugee or asylum seeker students are good at reading and writing. Since the instructors taught them daily speaking, these children started to have good communication with their friends and teachers, even with others. For example, at the end of the action research two refugee or asylum seeker girls stopped the researcher and asked where the instructors are. According to the IOM Report, "At this age, friends are more important than before". It has been determined that most of the interviewed children's friend environment was very limited". Friendship determines children's staying at school or participating school activities. Thus, having good communication with classmates and teachers will raise asylum seeker or refugee children's attendance at the school.

\section{The time of this particular education should be more.}

During the interviews of teachers, teachers stated that "yes, this education was helpful for these children; however since they don't speak, read or write the time of this education should be more and more". Once or twice a week wouldn't be very helpful because children should repeat what they learn every day. If the educations become every day, the process of children will be quicker.

\section{They start to communicate with Turks}

At the beginning of the study, refugee and asylum seeker students hesitated to talk with the researcher and instructors. Since they don't have any friends at school they were only playing and talking with students from their nationality; however, at the end of the study, these students were observed to talk and play with Turkish students. Besides, these students came near to the researcher and asked the instructors working with them. It shows that these students get used to Turkish people since they passed time with instructors and understand Turkish better than before.

Additionally, at the beginning of the study, these students were very shy and even they don't want to stay with the researcher and instructors. However, at the end of the study, these children wanted to be with instructors. Ones, two 
girls of these students asked the researcher "where are the sisters they are studying with?". Instructors couldn't have lessons that week; thus, these students missed them and asked the researcher where they are.

One of the refugee children's mother also requested to meet with the instructor because the children always talk about the instructor at home. The instructor and the mom met and spoke to the children ones. All these show that these kids need to have a special time for them to get used to Turkish people and schools.

\section{Having the European Union Project}

After interviewing with instructors and teachers, the researcher shared the results to the principal. The principal was jubilant about the results. Since the results of the action research are positive, the principal stated that they are preparing and European Union Project about refugee and asylum seeker students.

The last step of the action research is to reflect on the process, which is a crucial step since this is where the researcher and teachers review what has been done, determine its effectiveness, and make decisions about possible revisions for the future implementations. Although the researcher did reflections with instructors and the principal during the action research, reflection reviews hadn't been done with teachers during the plan. Thus, the researcher and teachers reflected the process at the end of the project about what has been done and what can be done for the plans. Recommendations for the plans are to communicate with parents first and told them the plan and start the action plan after all. Some of these children's attendance to school is at very low level. Thus, standard or special education isn't helpful in this case. However, teachers stated that if parents are aware of the plan they would send their kids to school regularly. Another reflection is to have education time more to get more positive results. As stated above, if these children get special education every day, they will learn quicker and adapted to the school easier.

\section{Discussion}

Turkey became a place for refugees from many countries especially Syria, Iraq, Iran, and Afghanistan. The rates of refugees and asylums are increasing. Refugees and asylum seeker people are having problems ensuring their stay in Turkey. Education is one of these problems. Even though refugee and asylum seeker children are attending schools in Turkey, they are having adaptation and communication problem.

To produce a solution to improve the refugee students' adaptation to the Turkish schools and classrooms by using action research approach which is often preferred for solving the problems encountered by the educators was the aim of this study. The action plan was developed and implemented for the three months.

Overall, the action plan implemented was useful. It helped some of the refugee and asylum seeker students read write and speak Turkish and adapted to the school, teacher and friends. Why some? Because some of these children didn't attend the school regularly. It can be said that regular and special education for refugee and asylum seeker children is a must. If Turkey is accepting these people to the country and provide them getting an education, this should be made right. Only registering these children to the schools doesn't solve the problem. Even though this solves the getting education problem, it causes another problem as an adaptation. To be able to adapt these children to Turkish schools, we should teach them Turkish first and have special times with these kids to make them feel comfortable like home. Otherwise, these kids continue just to come and go to school without having friends whom they will talk, play and laugh. If there is a problem, it should be solved entirely. To solve the refugee and asylum seeker children's education problem totally, we shouldn't only register them to schools we have to have special times with them to adapt them to schools, teachers, and friends.

Additionally, studies on refugee and asylum seeker children's education should be increased since Turkey is one of the countries being on migration flow. Other countries that get migration do many studies and alert teachers and schools about the refugee children and their psychologies. For example, in 2008 Strekavola and Hoot published a guideline aiming to "alert teachers and administrators to this problem so that they might be more likely to respond to the special needs of refugee children who arrive in their schools".

\section{References}

Andrew, S., \& Halcomb, E. J. (2009). Mixed methods research for nursing and the health sciences. C. H. I. P. S. http://dx.doi.org/10.1002/9781444316490

Atasu, T. R. (2012). Turkiye'de gocmen cocuklarin profili, sosyal politika ve sosyal hizmet onerileri hizli degerlendirme arastirmasi. Uluslararasi Goc Orgutu (International Organization of Migration), Isvicre (Sweden).

Cooper-Twamley, S. M. (2009). Action research and its effects on teacher efficacy: A mixed methods case study. (M.E. Thesis). Baylor University.

Creswell, J. W. (2005). Educational research: Planning, conducting, and evaluating quantitative and qualitative research (2nd ed.). Upper Saddle River, NJ: Merrill/Prentice Hall. 
Fraenkel, J. R., \& Wallen, N. E. (2003). Action research. In how to design and evaluate research in education (5th ed., pp. 571-597). Boston: Mcgraw-Hill.

Gardiner, H. W., \& Gander, M. J. (2001). Cocuk ve ergen gelisimi, (cev. Ali Donmez, Belir Onur, Nermin Celen), Imge: Ankara.

Icduygu, A., \& Toktas, S. (2002). How do smuggling and trafficking operate via regular border crossings in the Middle East? Evidence from fieldwork in Turkey. International Migration, 40(6), 27-54. http://dx.doi.org/10.1111/1468-2435.00222

Johnson, A. P. (2008). A short guide to action research (3rd ed.). Boston: Allyn \&Bacon.

Kartal, B., \& Basci, E. (2014). Turkiye'ye yonelik multeci ve siginmaci hareketleri, CBU Sosyal Bilimler Dergisi, 12(2), 275-299. http://dx.doi.org/10.18026/cbusos.42910

McMillan, J. H. (2004). Educational research: Fundamentals for the consumer (4th ed.) Boston: Allyn \&Bacon.

Mertler, C. A. (2014). Action research: Improving schools and empowering educators (4th ed.). California: Sage Publications.

Milli Egitim Bakanligi 2010 MEB Yabanci Uyruklu Ogrenciler Genelgesi. Retrieved from http://ogm.meb.gov.tr/belgeler/genelge_2010_48.pdf at 10.03.2015

Mills, G. E. (2001). Action research: A guide for the teacher researcher (4th ed.) Boston: Pearson.

Parsons, R. D., \& Brown, K. S. (2002). Teacher as reflective practitioner and action researcher. Belmont, CA: Wadsworth/Thomson Learning.

Recber, S. (2014). Hayatin yok yerindekiler: Multeciler ve siginmacilar. Presented at VI. Sosyal Insan Haklari Ulusal Sempozyumu.

Schmuck, R. A. (1997). Practical action research for change. Arlington Heights, IL: SkyLight Professional Development.

Seydi, A. R. (2014). Turkiye'nin Suriyeli siginmacilarin egitim sorununun cozumune yonelik izledigi politikalar, $S D U$ Faculty of Arts and Sciences Journal of Social Sciences, 31, 267-305.

Sinclair, M. (2007). Education in emergencies in Increasing access and the right to quality education. Commonwealth Education Partnerships.

Strekavola, E., \& Hoot, J. L. (2008). What is special about special needs of refugee children? Guidelines for teachers. Multicultural Education.

U.S. Committee for Refugees and Immigrants (2006). Principal sources of refugees. Retrieved March 8, 2015, from http://www. refugees.org/data/wrs/06/docs/principal_sources_of_refugees.pdf.

WCRWC (2001). Against all odds: surviving the war on adolescents - providing the protection and capacity of Ugandan and Sudanese adolescents in Northern Uganda. New York: Women's Commission for Refugee Women and Children.

WCRWC (2002). Precious resources: adolescents in the reconstruction of Sierra Leone. New York: Women's Commission for Refugee Women and Children.

WCRWC (2005). Learning in a war zone: education in northern Uganda. New York: Women's Commission for Refugee Women and Children

Westhues, A., Ochocka, J., Jacobson, N., Simich, L., Maiter, S., Janzen, R., \& Fleras, A. (2008). Developing theory from complexity: Reflections on a collaborative mixed method participatory action research study. Qualitative Health Research, 18(5), 701-717. http://dx.doi.org/10.1177/1049732308316531

Winthrop, R., \& Kirk, J. (2005). Teacher development and student well-being. Forced Migration Review, 22, 18-21.

Yildiz, O. (2013). Turkiye kamplarinda Suriyeli siginmacilar: Sorunlar, beklentiler, Turkiye ve gelecek algisi. Journal of Sociological Research, 16(1), 141-169.

Yuladir, C., \& Dogan, S. (2009). Fen ve Teknoloji Dersinde Ogrencilerin Ev Odevi Performansini Arttirmaya Yonelik Bir Eylem Arastirmasi. Cankaya University Art and Sciences Faculty, Journal of Arts and Sciences, 12, 211-238.

\section{$(\mathrm{Cc}) \mathrm{BY}$}

This work is licensed under a Creative Commons Attribution 3.0 License. 